\title{
When to start with science teaching in academic medicine?
}

\author{
Mevludin Hasanović ${ }^{*}$ \\ Department of Psychiatry, University Clinical \\ Center Tuzla, Bosnia and Herzegovina \\ ${ }^{\star}$ Corresponding author: \\ hameaz@bih.net.ba \\ Tel.: +38761656608 \\ Fax.: +38735268011
}

Received: 23 May 2015

Accepted: 26 May 2015

Key words: Mentoring - Science teaching Academic medicine

In academic medicine, mentoring was recognized to have an important influence on personal development, career choice and navigation, and research productivity (1). For this purpose, it is essential to have mentoring of high quality during the entire process of scientific research and academic degrees achievement (2). Sambunjak's article offers a holistic view of mentoring in academic medicine that may help one comprehend and appreciate the complexity of influences on mentoring, and inform the future research agenda on this important topic (2). Presented model needs to be recognized and known internationally.

The Joint Declaration of the European Ministers of Education in 1999, defined in the Bologna, needs to reshape the future of academic medicine in Europe, related to the ongoing restructuring and harmonization of a higher education (3). Bosnia and Herzegovina has the additional heavy burden of immense war destruction and population migration, which also affected medical education (3-6). In such ambient even medical students are prone to academic cheating (7).

Despite strategies proposed to alleviate the problems, research in most small and developing countries lags behind the countries belonging to the so-called mainstream science (8). According to Zerem (9) "the root of the problem in Bosnian academia - the lack of internationally recognized criteria in the acquisition of academic titles - is rarely discussed. The growing number of Masters Degrees, PhDs, and other academic titles does not reflect the reality of the scientific community. Absurdly, there is a huge number of scientists, but poor scientific production" (9).

Obligatory science teaching in medical schools in Bosnia and Herzegovina could help in building of better perspectives of academic medicine. Indeed, the group of enthusiasts, over the last 20 years, through their work as educators and editors of general medical journals dedicated to publishing research from small scientific communities has recognized that researchers from developing countries often lacked adequate training in critical assessment, research methodology and statistics. To address these prob- 
lems in their own country and prevent them at their core they introduced an obligatory science teaching in medical schools in Croatia. The scientific evaluation of their course showed that they successfully satisfied the European Directive 2005/36/EC, which required, that all medical students upon graduation have: "Adequate knowledge of science upon which medicine is based, and good comprehension of scientific methods, including the principles of biological functions and assessment of measuring biological functions, the evaluation of scientifically established facts and the analysis of data" (8).

Conflict of interest: The author declares that he has no conflict of interest.

\section{References}

1. Sambunjak D, Straus SE, Marusic A. Mentoring in academic medicine: a systematic review. JAMA. 2006;296:1103-15.

2. Sambunjak D. Understanding wider environmental influences on mentoring: Towards an ecological model of mentoring in academic medicine. Acta Med Acad. 2015;44(1):47-57. DOI: 10.5644/ ama2006-124.126.
3. Marušić A. Future of academic medicine. Acta Med Acad. 2006;35:1-8.

4. Hasanović M. Psychological consequences of wartraumatized children and adolescents in Bosnia and Herzegovina. Acta Med Acad. 2011;40(1):4566. DOI: 10.5644/ama2006-124.8.

5. Hasanović M, Srabović S, Rašidović M, Šehović M, Hasanbašić E, Husanović J, et al. Psychosocial assistance project decreases posttraumatic stress disorder and depression amongst primary and secondary schools students in post-war BosniaHerzegovina. Acta Med Acad. 2011;40(2):122-31. DOI: 10.5644/ama2006-124.15.

6. Agius M, Glaurdic J. Remembering wars past. Paediatrics Today. 2012;8(1):1-4. DOI: 10.5457/ p2005-114.31.

7. Đogaš V, Jerončić $A$, Marušić $M$, Marušić $A$. Who would students ask for help in academic cheating? Cross-sectional study of medical students in Croatia. BMC Med Educ. 2014;14:1048. DOI: 10.1186/s12909-014-0277-y.

8. Marušić A, Malički M, Sambunjak D, Jerončić A, Marušić M. Teaching science throughout the sixyear medical curriculum: two-year experience from the University of Split School of Medicine, Split, Croatia. Acta Med Acad. 2014;43(1):50-62. DOI: 10.5644/ama2006-124.100.

9. Zerem E. Right criteria for academia in Bosnia and Herzegovina. Lancet. 2013;382(9887):128. DOI: 10.1016/S0140-6736(13)61565-2. 